УДК 94(4); ББК 63.3(4)5+68.35; DOI https://doi.org/10.21638/spbu19.2021.203

P. Gawron

\title{
ORGANIZATIONAL TRANSFORMATIONS OF THE CROWN ARMY DURING THE WAR OF THE VISTULA MOUTH, 1626-1629*
}

On $6^{\text {th }}$ July 1626, the Swedish army, under the personal command of King Gustav II Adolf, took over the port in Pillau (Piława) that belonged to Duke Georg Wilhelm of Prussia, and afterwards moved to conquer Royal Prussia, soon conquering Elbląg, Braniewo, and Malbork. Ruling the Polish-Lithuanian state, Sigismund III rallied numerous troops relatively quickly and set off to help the inhabitants of Gdańsk. In this way the last stage of the struggles of the Polish-Lithuanian Commonwealth with Sweden in the first half of the $17^{\text {th }}$ century began, in Polish literature called the War for the Vistula Mouth, and in Swedish fålttågen i Preussen ${ }^{1}$. At stake in the conflict was control of Gdańsk, one of the most powerful cities of East-Central Europe at that time, along with its direct economic base: the fertile and well managed Royal Prussia. For the Swedes, taking Prussia was another step towards making the Baltic Sea their own pond (dominium Maris Baltici). The Poles, only to a small degree supported by the Lithuanians, who struggled with the Scandinavians in Livonia, fought for maintaining control over the Vistula River, the most important commercial artery in the country.

The first clashes, especially the siege of Mewe (Polish Gniew) and the three-day battle at that castle at the turn of October $1626^{2}$, showed that the reformed Swedish army, perfectly commanded by Gustav II Adolf, would be a hard nut to crack by Sigismund III's soldiers ${ }^{3}$.

* The article was written as part of the research project of the National Centre for Science SONATA, no. $2016 / 23 / \mathrm{D} / \mathrm{HS} 3 / 03210$ «The military revolution as a modernization factor in the public finance and state organization of the Polish-Lithuanian state in the comparative perspective» ${ }^{1}$ A concise description of the war can be found in: Frost R. I. The Northern Wars. War, state and society in Northeastern Europe, 1558-1721. Harlow, 2000. P. 104-114; Generalstaben: Sveriges krig 1611-1632. Bd II: Polska Kriget. Stockholm: Victor Pettersons Bokindustriaktiebolag, 1936. S. 236-456.

${ }^{2}$ Teodorczyk J. Bitwa pod Gniewem (22.IX-29.IX-1.X.1626). Pierwsza porażka husarii // Studia i Materiały do Historii Wojskowości. 1966. T. XII. Cz. 2. S. 70-172.

${ }^{3}$ The Swedish army was recently discussed by: Fredhom von Essen M. The Lion from the North. Vol. 1: The Swedish Army during The Thirty Years War, 1618-1632. Warwick, 2020; Frost R. I.

(C) P. Gawron, 2021 
The Polish cavalry was not able to break the lines of the Swedish infantry hidden behind a field fortification erected at a dizzying pace, having great firepower, and supported by numerous and well-prepared artillery. It also had increasingly serious problems in the fight with the enemy's cavalry, which perfectly cooperated with infantry, using its support when necessary. The Swedish infantrymen dominated in numbers, training, and combat experience over the Poles and Lithuanians, who not only could not pave the way for the charging cavalry, but also had troubles stopping the attacking enemy. The feeble and badly commanded artillery of the Polish king was no good combat with the enemy in battle; it also failed during the siege of Gniew. Sigismund III and his advisors, particularly Grand Crown Field Hetman Stanisław Koniecpolski, did not ignore the problem and made attempts to reform the army.

The organizational transformations of the Crown Army during the War for the Vistula Mouth are primarily discussed on the basis of fiscal and military sources: Parliamentary accounts, fiscal-military committees' reckoning, and army registers (so-called komput). In the case of this category of sources, it is crucial to bear it in mind that the numbers of Crown troops were overstated, which is particularly conspicuous in the komput of Crown troops prepared in September 1629, where the official number is considerably different from the real figure ${ }^{4}$. Unpaid troops effectively demanded the recognition of the official numbers as the real one, explaining it as necessary for gaining compensation for damages resulting from their long service without remuneration, to which the state authorities had to agree willy-nilly. This was indispensable to reach correspondence and various descriptions of warfare.

Jerzy Teodorczyk estimated the number of Sigismund III's troops in the Battle of Mewe as 11,210 men, of which 6,780 were cavalry, while 4,430 made up the infantry. These forces were supported by twenty cannons, including seven heavy ones, two medium-sized, and eleven light ones. Bearing in mind the fact that the royal forces were composed of a jumble of the king's private troops and dignitaries accompanying him, pospolite ruszenie (noble levy en masse), the Lisowczycy and Lithuanian mercenary troops, it is important to note the preponderance of the cavalry over the infantry in a ratio 60 to 40 . The ratio partly resulted from the way of rallying the army: for most senators, officials, and regular noblemen it was easier to recruit mounted poczty (small cavalry units) than infantry, and this also partly resulted from the king and his entourage's belief in the efficiency of the Polish-Lithuanian cavalry, which was not upset even by the recent failures in Livonia, particularly the Batttle of Wallhof (Polish: Wallhof) of 17 January 1626, where Gustav II Adolf defeated the Grand Lithuanian Marshall Jan Stanisław Sapieha who commanded the Lithuanian army ${ }^{5}$.

The monarch and his advisers, particularly Hetman Koniecpolski, soon understood that the traditionally organized Polish army would not be able to take the challenge and fight the Swedes without support from the infantry, dragoons, and artillery. The first attempts at reforms

The Northern Wars... P. 114-128. — About Polish forces see: Paradowski M. Despite destruction, misery and privations... The Polish Army in Prussia during the war against Sweden 1626-1629. Warwick, 2021. - Here I want to express my thanks to the author for sharing his draft with me. ${ }^{4}$ On the basis of the register of part of the army: cavalry of the national contingent, reiters, and dragoons, carried out on 15 September 1629, it turned out that the army had 3,363 soldiers, which constituted merely around $48 \%$ of the whole number, being 7,032 soldiers' pay rates: Pułk hetmański // AGAD. Archiwum Zamoyskich. MS 3116. S. 10-12.

${ }^{5}$ Teodorczyk J. Bitwa pod Gniewem... S. 95; Wisner H. Wojna inflancka 1625-1629// Studia i Materiały do Historii Wojskowości. 1970. T. XVI. Cz. 1. S. 62-74. 
began in autumn 1626, before companies from Red Ruthenia arrived in Prussia. The direction of the changes is well illustrated in Figure 1, which compares the army of Sigismund III rallied in Prussia at the beginning of November, and the wojsko kwarciane (quarter army) concentrated in Ukraine in the summer 1626 to defend the southern border from the Tatars. The basis for the analysis includes two published registers: Wojsko Kwarciane na polu w roku 1626 oraz Popis wojska dziewiąci tysięcy przed Królem Je. M. pod Arciberzem a Pszczewem 4 Nov. ${ }^{6}$

Figure 1. Organization of the Polish Armies: Northern and Southern: as in 1626

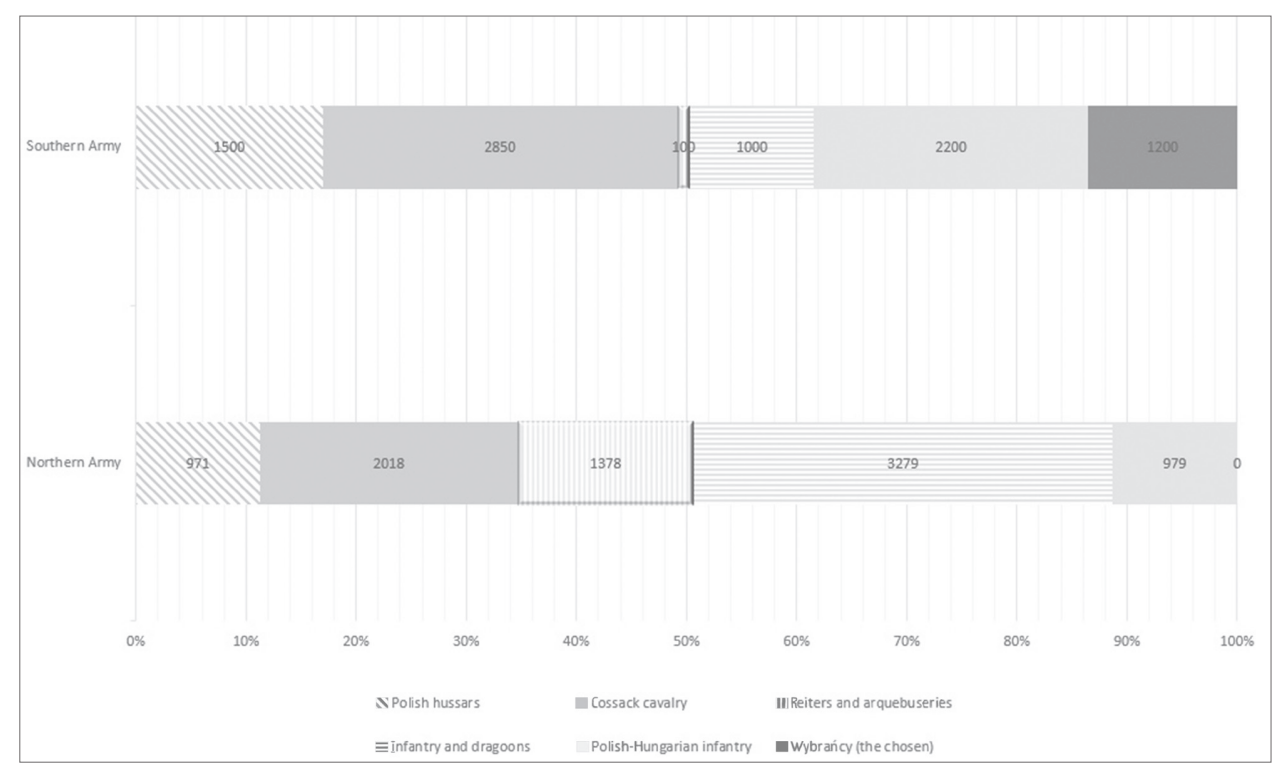

Prepared by the author on the basis of: Wojsko Kwarciane na polu w roku 1626; Popis wojska dziewiąci tysięcy przed Królem Je. M. pod Arciberzem a Pszczewem 4 Nov. // Paradowski M. Studia i materiały do historii wojen ze Szwecją 1600-1635. Oświęcim, 2013. S. 85-87, 106-110.

With the similar number of both armies, an analysis of data allows us to perceive clear differences. In the Prussian troops, slowly prepared for fire fight and positional warfare against the Swedes, infantry along with dragoons constituted nearly half of forces, while in the South, where the principal enemy were mobile Tatars, slightly over $2 / 5$ of all the forces. In the ranks of the cavalry in the Prussian troops were a considerable number of German reiters, who were used during the autumn fights with the Swedes not only to break cavalry, but also to exchange fire with the enemy. In the South, reiters were almost absent; most of the cavalry were Polish hussars and light Cossack cavalry ${ }^{7}$, better prepared to fight the subjects of the Crimean khan

${ }^{6}$ Paradowski M. Studia i materiały do historii wojen ze Szwecją 1600-1635. Oświęcim, 2013. S. 85-87, 106-110.

${ }^{7}$ About light Cossack cavalry in the Commonwealth see: Boldyrew A., Łopatecki K. Polish Way: The Light Cossack Cavalry in the Era of Military Revolution // Vestnik of St. Petersburg University. History. 2020. Vol. 65. Issue 3. P. 683-709. - It is important to note, that light Cossack cavalry should not be confused with more famous Zaporozhian Cossacks, because they were two quite different formations. 
thanks to their mobility. We should not ignore the fact that in Sigismund III's army, the infantry of the foreign contingent and the dragoons clearly outnumber the Polish-Hungarian model infantry, whereas the units of the foreign contingent (reiters, dragoons, infantry) constituted slightly over a half of all the forces. In the south the foreign infantry ${ }^{8}$ made up nearly a third of the whole infantry, like the Polish-Lithuanian contingent. The most numerous group among the infantrymen were the Select Infantry (Wybrańcy), absent in Prussia9.

The comparison above is somewhat misleading, since the monarch summoned Koniecpolski to Prussia as soon as July, and if the threat of a Tatar raid had not stopped the hetman for longer in Ukraine, the structure of the Royal army in Prussia would have resembled more the organization of the Quarter Army (wojsko kwarciane). Nevertheless, it is important to note a higher number of reiters in the north and the simultaneous fall in importance of hussars and light Cossack cavalry, as well as the domination of foreign contingent infantry and dragoons over the Polish-Hungarian infantry.

According to different fiscal accounts ${ }^{10}$, in the period 1 December $1626-30$ November 1627, the Crown army in Prussia contained 17-19 hussar companies ${ }^{11}$, of 2,026-2,380 horses, as well as 29 light Cossack companies (3,295-3,650 horses), depending on the quarter and the source. They were grouped in seven regiments, where the Polish hussars and the Cossack cavalry occurred jointly ${ }^{12}$. This division was no novelty; for instance the Crown army was organized in this way during operations against Michael the Brave in Moldavia and in Wallachia. Also, the Polish-Lithuanian troops during the campaign of 1621 at Hotin had

${ }^{8}$ Considerable doubts are raised by the status of the units of Wilhelm (William?) Winterot (Winteroy, Winter), Jakub (James?) Butler and Wilhelm (William) Leslie (Lesse). The komput defines them as infantry; the first of the aforementioned captains also occurs as an infantry commander in noblemen protestations registered in the castle register of Lvov (ksiega Grodzka lwowska) in the years 1625-26 (Центральний Державний Історичний Архів України, м. Львів (ЦДІАУЛ). Ф. 9. Оп. 1. Спр. 377. С. 5-6, 1256-1257). In Prussia, however, they occurred as dragoon units, which was noted by: Wimmer J. Wojsko i skarb Rzeczypospolitej u schyłku XVI i w pierwszej połowie XVII wieku // Studia i Materiały do Historii Wojskowości. 1968. T. XIV. Cz. 1. S. 43. Footnote 178.

${ }^{9}$ About Wybrańcy see: Kupisz D. The Polish-Lithuanian Military in the Reign of King Stefan Bathory (1576-1586) // Warfare in Eastern Europe, 1500-1800. Leiden; Boston, 2012. P. 69.

${ }^{10}$ Regestrum rationis thesauri Regni in Conventu a. 1629 expeditae (later as - Regestrum rationis...) // Biblioteka Muzeum Książąt Czartoryskich w Krakowie. MS 1772. S. 348-440; Komput woyska KJM zaciągu do Prus w służbie będącego y wiele się mu winno (later as — Komput zaciągu do Prus...). Svenska Riksarkivet. Stockholm. Skokloster Sammlingen. MS E 8600. F. 179-182 v.; Komput woyska K. r. m. [s] koronnego zaciągu dawnego (later as - Komput zaciągu dawnego...). Svenska Riksarkivet. Stockholm. Extranea IX Polen. Vol. 82 (no page numbers).

${ }^{11}$ The point is that in Komput zaciągu dawnego... two companies: that of Andrzej Kossakowski, the Vizna cup-bearer (podczaszy) (depending on the quarter from 95 to 100 horses) and Mikołaj Gniewosz (80-125 horses) occur as reiter companies. If we recognize them as hussar companies, the number of hussar horses will be 2,301, and after taking them away, 2,026 horses.

${ }_{12}$ Diarius wojny w Prusach // Biblioteka Kórnicka Polskiej Akademii Nauk. MS 201. F. 289 v. Slightly different view in: Diariusz albo summa spraw i dzieł wojska kwarcianego w Prusiech na usłudze Jego Królewskiej Miłości przeciwko Gustawowi książęciu Sudermańskiemu będącego w latach 1626, 1627 i 1628 // Pamiętniki o Koniecpolskich. Przyczynek do dziejów polskich XVII wieku / Red. Stanisław Przyłęcki. Lwów, 1842. S. 14. 
a similar structure ${ }^{13}$. The regiment performed operational, tactical, and administrative tasks, although the hetman frequently waged hostilities, e. g. sending troops to watch or to raid, or combining units from different regiments. This structure was also used for fiscal purposes as a base for financial settlements with the military.

The core of reiter units was made up of regiments of Mikołaj Abramowicz, the Smolensk wojewodzic, and Ernest Denhoff, which received pay from the Crown treasure from November 1626 onward. During the campaign of 1627, six new extra companies were accepted for service, four of which were coopted into Denhoff's regiment, while two kept the status of independent units (of Duke Oktawian Proński and Gotard Bodembruch). The number of the reiters oscillated between 551 at the turn of 1627 and 1,117 in November $1627^{14}$.

At the latest in 1627, the fiscal accounts contained a note about a salary for the PolishHungarian infantry captain. Samuel Nadolski received initially a sum of 500 Polish zlotys, which constituted an equivalent of the pay of five hussar horses (50 zlotys per horse) for two quarters (half a year). In a later period, the amount of the salary was $800-1,000$ zlotys ${ }^{15}$. Unfortunately, on the basis of available sources it is not possible to determine the competence scope of the new member of the hetman's staff. It is difficult to establish the number of soldiers in the Polish infantry. We can only state with certainty that between 1 December 1626 and 30 May of the following year, 1,200 soldiers were in service, whereas after the debates of the Torun Diet, it was planned to recruit 1,400 more $^{16}$. We do not know exactly the result of that attempt, but there is no doubt that in Prussia there were companies of at least four new captains (Tryzna, Piotr Kurecki, Wojciech Pepłowski and Kasper Śliwnicki), which would be around 1,000 new soldiers.

Over the whole year 1627 maximum six companies of dragoons, were noted in the Crown army, and they included 411-1,608 soldier's pay rates ${ }^{17}$. Definitely, the most numerous was the representation of the foreign model infantry contingent. In the ranks of 21 units, including two larger regiments, there were 4,338-5,523 pay rates ${ }^{18}$. The sources under analysis do not allow

${ }^{13}$ Skorupa D. Bitwa pod Bukowem 20 października 1600 r. // Staropolska sztuka wojenna XVI-XVIII wieku. Prace ofiarowane Profesorowi Jaremie Maciszewskiemu. Warszawa, 2002. S. 38-42; Żojdź K., Hundert Z. Komput chocimski 1621 z rękopisu Biblioteki Narodowej // Studia nad staropolską sztuką wojenną. T. II. Oświęcim, 2013. S. 245-257.

${ }^{14}$ Regestrum rationis... S. 441-451; Roty rajtarskie pułku Jmci pana Mikołaja Abramowicza wojewodzica smoleńskiego // AGAD. Archiwum Zamoyskich. MS 3112. S. 283-288; Komput zaciągu dawnego...

${ }^{15}$ Komput zaciągu dawnego...; Regestrum rationis... S. 537; Rachunek Skarbu Koronnego z 1629 r. / Red. Ferdynand Bostel. Kraków: Akademia Umiejętności, 1891. S. 39.

${ }^{16}$ Komput zaciągu dawnego... - The presence of Kurecki, Pepłowski and Śliwnicki in Prussia in 1628 is confirmed by the document: Usarze // Svenska Riksarkivet. Stockholm. Extranea IX Polen. Vol. 80 (no page numbers) (later as - Usarze...), and the presence of Tryzna in Prussia in 1627 is confirmed in: S. Koniecpolski's letter to Sigismund III, camp at Rozenborg 24 August 1627 // Biblioteka Jagiellońska. MS 211. F. 37.

${ }^{17}$ Regestrum rationis... S. 476-495. - In the light of the document, there existed only two dragoon units: of Bazyli Judycki and Andrzej Ratke. «Komput zaciągu dawnego... enumerates six units of 1,152 pay rates; Komput zaciagu do Prus...» mentions four dragoon units of 1,432 pay rates, to which we may add Andrzej Kiet's (Kieth's) and Andrzej Retken's (Radke's) dragoons, which results in total in 1,608 pay rates.

${ }^{18}$ Regestrum rationis... S. 454-495; Komput zaciągu dawnego...; Komput zaciągu do Prus... S. 181-182. 
us to assess the number of Elected Infantry, although drawing conclusions from subsequent years it seems that the presence of those formations in Prussia in 1627 is very possible. The army's structure was shown on Figure 2.

Figure 2. The Crown Army in Prussia in 1627

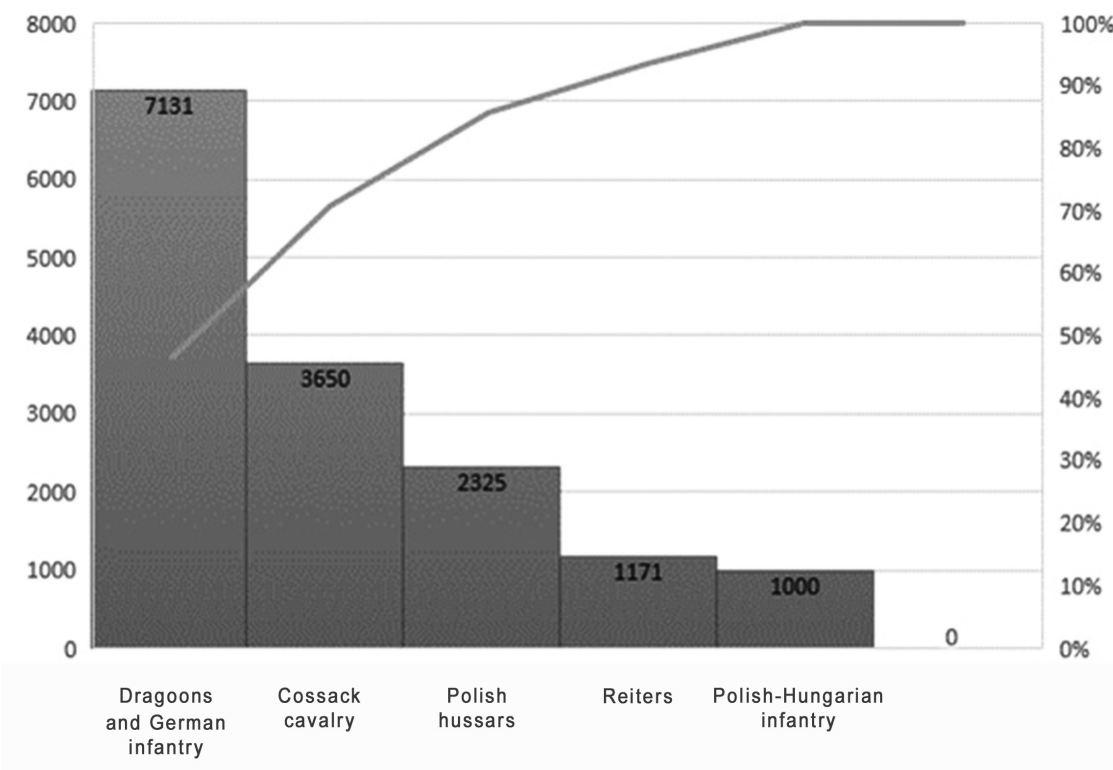

Prepared by the author on the basis of: Regestrum rationis thesauri Regni in Conventu a. 1629 expeditae // Biblioteka Muzeum Książąt Czartoryskich w Krakowie. MS 1772. S. 348-504; Komput woyska KJM zaciągu do Prus w służbie będącego y wiele się mu winno // Svenska Riksarkivet. Stockholm. Skokloster Sammlingen. MS E 8600. F. 179-182 v.; Komput woyska K. r. m. [s] koronnego zaciągu dawnego // Svenska Riksarkivet. Stockholm. Extranea IX Polen. Vol. 82 (no page numbers); Roty rajtarskie pułku Jmci pana Mikołaja Abramowicza wojewodzica smoleńskiego // AGAD. Archiwum Zamoyskich. MS 3012. S. 283.

In 1627, the German reiters played a much greater a role in the Prussian army than in Ukraine, which is well visible during the warfare in the first half of the year ${ }^{19}$, whereas in the ranks of cavalry they took third place, being less numerous than the hussars and the Cossacks. The number of reiters was surely affected by difficult living conditions in the winter camp at the end of 1626; hence the low numbers of persons in the first half of the following year, which later on doubled. On the other hand, it is difficult to imagine Koniecpolski's army without the foreign model infantry contingent, which constituted, besides dragoons, slightly over three quarters of the whole infantry and $43 \%$ of all the forces. If we assume that the Crown army had a maximum of around 15,277 pay rates, the infantry constituted around $53 \%$ of this number. Further, we note the fluidity of the line between an infantryman and a dragoon, since the units defined in certain documents as dragoons were called infantry in others. We may guess that dragoons became infantrymen after losing horses, at least from the point of view

${ }_{19}$ Teodorczyk J. Wyprawa szwedzka z Meklemburgii do Prus Królewskich wiosną 1627 r. // Studia i Materiały do Historii Wojskowości. 1960. T. VI. S. 100-190. 
of fiscal scribes. Our attention is also drawn by the appointment of the captain of the PolishHungarian model infantry, about whose competences, in comparison with other captains of that formation, it is difficult say much.

In 1628 the structure of the cavalry remained basically intact. The seven cavalry regiments of the Polish contingent included twenty companies of Polish hussars (2,224-2,274 horses) and 29 light Cossack cavalry units (3,521-3,600 horses). Also, the structure of German reiter units did not change: two regiments (of M. Abramowicz and Ernst Magnus Denhoff) and two free companies contained altogether 1,230-1,295 pay rates. It was similar in the case of the companies of the Polish-Hungarian infantry, where after September 1628 nine of them included 1,850 servants $^{20}$.

The most serious changes occurred in the organization of the foreign model infantry. As late as in the first months of 1627, an idea was conceived in the royal court to organize this formation in large regiments that would replace free companies. The king gained the approval of the idea from Koniecpolski, who, however, asked the king not to issue new recruitment documents for free companies ${ }^{21}$. Therefore, as we can assume, the king granted Ernest Magnus and Gerhard Denhoffs two letters authorizing them to recruit in Germany large units, of three thousand pay rates each ${ }^{22}$, and made an attempt to subordinate all or some of the units of infantry and dragoons in the camp to Gustav Sparre. The monarch's idea was only partly successful. The recruitment in Germany engulfed in war all came to naught, and the Denhoffs brought slightly more than 1,800-2,000 soldiers to the camp, i. e. a third of the originally planned number ${ }^{23}$. Sparre, who appeared in the army at the turn of 1628, faced successful resistance from at least some officers, such as Bazyli Judycki, who refused to resign from his independent command ${ }^{24}$. As a result, during the campaign of 1628 the Prussian army had two infantry regiments (of Sparre and Gerhard Denhoff), one infantry-dragoon regiment (of James Butler ${ }^{25}$ ) and five free companies, one of which under the command of Patrick Gordon was put into service in August of that year. In the light of the collective accounts prepared for fiscal purposes by the fiscal-military commission in Torun in November 1628, in the spring of that year they had 7,427 pay rates, and then and additional 986 rates were recruited ${ }^{26}$. The army

\footnotetext{
${ }^{20}$ Regestrum rationis... S. 341-457, 501-502.

${ }^{21}$ Stanisław Koniecpolski to P. Gembicki, Starogard, 15.V.1627 // Biblioteka Jagiellońska. MS 211. F. 85.

${ }^{22}$ M. E. Denhoff to K. Radziwiłł, Warszawa, 17.I.1627 // AGAD. Archiwum Radziwiłów. Dz. V. MS 2968. S. 118-120.

${ }^{23}$ S. Koniecpolski to P. Gembicki, camp near Brzusiec (Brzuzne?), 20.VI.1627 // Biblioteka Jagiellońska. MS 211. F. 69; Komput zaciągu do Prus...

${ }_{24}^{2}$ [Bazyli] Judycki to N. N. [Z. K. Radziwiłł], camp, 2.III.1627 // AGAD. Archiwum Radziwiłłów. Dz. V. MS 6171. S. 1-3; Regestrum rationis... S. 452; Komput zaciągu do Prus...

${ }^{25}$ The Diet account for the years 1627-28 defined all the companies of that regiment as infantry, but the relations referring to the hostilities mention both infantry and dragoons. The letter of Jakub Zadzik to Sigismund III, Prabuty, 9.II.1628 // Biblioteka Zakładu im. Ossolińskich we Wrocławiu. MS 209. F. 108 v. refers to the first case. Dragoons appeared, for example, in: S. Koniecpolski's letter to Sigismund III, [Bydgoszcz], 9.V.1628 // Biblioteka Zakładu im. Ossolińskich we Wrocławiu. MS 209. F. 235.

${ }^{26}$ Regestrum rationis... S. 452-499; Komput piechoty cudzoziemskiej na komissyjej bydgoskiej uczyniony i na sejmie podany i co go po sejmie i komissyjej bydgoskiej przybyło // Biblioteka Zakładu im. Ossolińskich we Wrocławiu. MS 209. F. 540 v. Slightly different versions: Summariusz
} 
structure is shown on Figure 3. Judging by the course of hostilities, as well as the dislocation of the army, the regiments had mainly an administrative and fiscal function, whereas it often happened that particular companies were scattered all over the war theater and took part in the operations separately. For example, at the beginning of 1629, companies of Sparre's regiment were in Puck, Lubawa, Golub, Gniew, Olsztynek and in some undefined place in Ermland ${ }^{27}$.

Figure 3. Crown Army in Prussia in 1628-1629

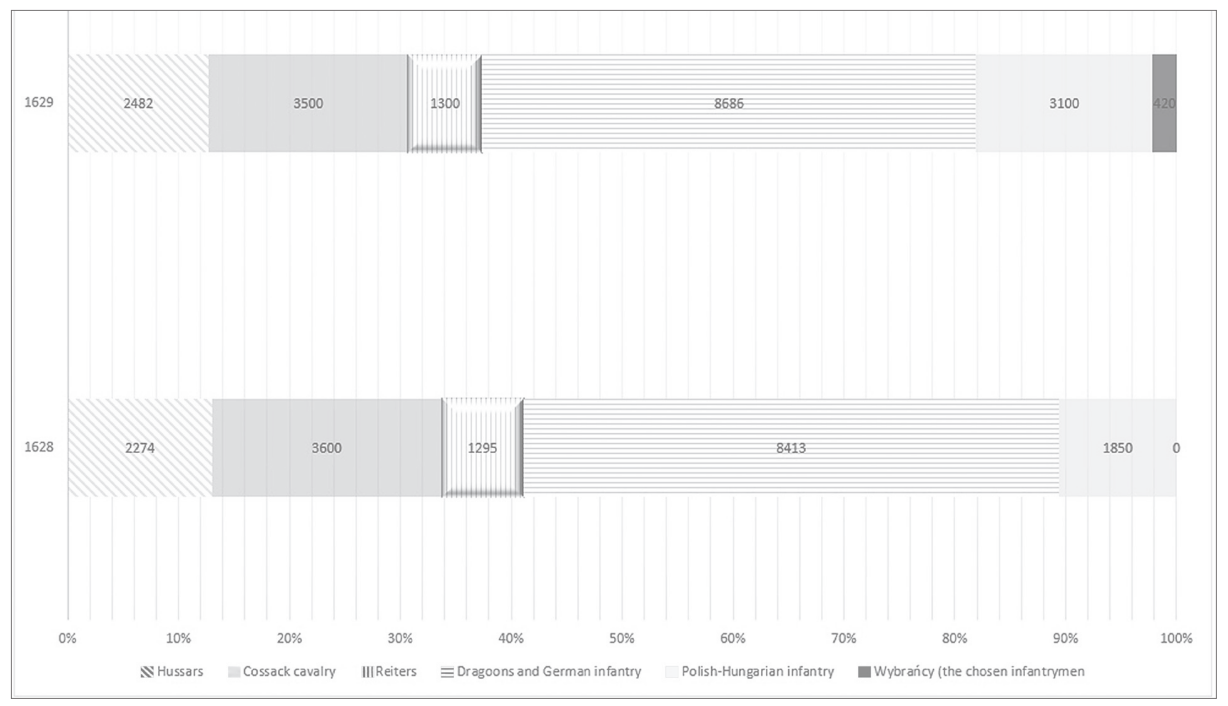

Prepared by the author on the basis of: Regestrum rationis... S. 348-504; Roty rajtarskie pułku Jmci pana Mikołaja Abramowicza wojewodzica smoleńskiego // AGAD. Archiwum Zamoyskich. MS 3012. S. 283; Komput piechoty cudzoziemskiej na komissyjej bydgoskiej uczyniony i na sejmie podany i co go po sejmie i komissyjej bydgoskiej przybyło // Biblioteka Zakładu im. Ossolińskich we Wrocławiu.

MS 209. F. 540 v.; slightly different versions: Summariusz ekspensy co wojsko pruskie brało ad rationem z skarbu reszty po sejmie przeszłym 1627 et 1628 // Biblioteka Raczyńskich w Poznaniu. MS 233. F. 317; Summariusz co brało wojsko pruskie ad rationem z skarbu Rzeczypospolitej po sejmie blisko przeszłym i co mu Rzecz pospolita winna a 1 Decembris A. 1626 a 1 Septembris A. 1628 // Biblioteka Muzeum Książąt Czartoryskich w Krakowie. MS 2246. S. 115; Pułk hetmański // AGAD. Archiwum Zamoyskich. MS 3116. S. 10; Komput wojska JKM // Svenska Riksarkivet. Stockholm. Extranea IX Polen. Vol. 80; Usarze // Svenska Riksarkivet. Stockholm. Extranea IX Polen. Vol. 80; Rationes thesauri regni perceptae atque distributae pecuniae publicae in commissione leopoliensi // Центральний державний історичний архів України, м. Львів. Ф. 9. Оп. 1. Спр. 381. С. 1621; Rachunek Skarbu Koronnego z 1629 r. / Red. F. Bostel. Kraków: Akademia Umiejętności, 1891. S. 29-31.

In 1629 the organization of the Crown army in Prussia was not subjected to any more serious changes. In the light of various sources, six cavalry regiments comprised 18-19 hussar

ekspensy co wojsko pruskie brało ad rationem z skarbu reszty po sejmie przeszłym 1627 et $1628 / /$ Biblioteka Raczyńskich w Poznaniu. MS 233. F. 317; Summariusz co brało wojsko pruskie ad rationem z skarbu Rzeczypospolitej po sejmie blisko przeszłym i co mu Rzecz pospolita winna a 1 Decembris A. 1626 a 1 Septembris A. 1628 // Biblioteka Muzeum Książąt Czartoryskich w Krakowie. MS 2246. S. 115.

${ }^{27}$ Usarze... 
companies (2,300-2,480 horses) and 28 light Cossack cavalry troops of 3,450-3,500 horses. The reduction of the number of heavy cavalry units was probably connected with the deaths of two officers: Colonel Stefan Koniecpolski and Tomasz Szkliński, whose companies do not occur in the available fiscal sources. Also, the organization of German reiters including $1,197-1,300$ pay rates did not change ${ }^{28}$.

The number of the Polish-Hungarian model infantry considerably grew, because it was assumed that eighteen companies would include 3,100 pay rates, but we do not know if all the units reached Prussia before the September armistice in Altmark. The sources also mention three units of wybrańcy (the Elected Infantry) from Wielkopolska Mazowsze and Podlasie, with a total of 420 henchmen. Dragoons gathered in five companies, including two newly recruited ones, were at most 1,168 pay rates ${ }^{29}$. In the case of the foreign model infantry, there are discrepancies concerning the structure in the available sources. In one course, Komput wojska JKM independent companies do not occur. Their place was taken by large regiments, and the choragiew of colonel James Butler is referred to as that of dragoon, while Judycki's and Rokier's companies have the status of infantry. A sign of a serious transformation was the appearance in Prussia of Reinhold Rosen's regiment, which nominally comprised $1,000-1,100$ pay rates. The inhabitants of the Crown served, or were to serve, trained and armed in the German manner, which was an implementation of the increasingly frequent postulates to abandon recruiting a great number of expensive foreigners, and instead to train Polish own infantry in their image and likeness ${ }^{30}$. The number of foreign infantry may be cautiously estimated at least 7,518 pay rates ${ }^{31}$.

In comparison with the previous years, in 1629 one can note a clear weakening of the position of the cavalry in the Crown army's structure, which was largely caused by problems with recruiting new captains ${ }^{32}$. Infantry made up nearly $63 \%$ of all forces, with the reservation that all units whose recruitment had been planned reached Prussia. The core of that number was made up by dragoons and foreign model infantry, which were over $70 \%$ of the whole formation. The army's structure is clearly visible on Figure 3. It is, however, important to note striving for the polonization of the army through increasing the number of the PolishHungarian infantry, as well as creating Rosen's regiment. It is possible that problems with

${ }^{28}$ Usarze...; Komput wojska JKM // Svenska Riksarkivet. Stockholm. Extranea IX Polen. Vol. 80. For the record, it is important to mention that the presence of Stefan Koniecpolski's company was noted by the author of: Kontynuacji djarjusza o dalszych postępkach wojennych z Szwedami a die 1 Julii (1629). (Przyczynki do działań hetmana polnego koronnego Stanisława Koniecpolskiego w Prusach Wschodnich i na Pomorzu przeciwko Gustawowi Adolfowi) / Red. Otton Laskowski // Przegląd Historyczno-Wojskowy. 1936. T. IX. S. 434.

${ }^{29}$ Komput wojska JKM...; lower numbers occur in: Usarze...

${ }^{30}$ Wimmer J. Historia piechoty polskiej do roku 1864. Warszawa, 1978. S. 162; Nagielski M.

1) Reinhold Rosen // Polski Słownik Biograficzny. T. XXXII. Wrocław, 1989. S. 60-62;

2) Staropolska sztuka wojenna na tle przemian w zachodnioeuropejskiej wojskowości w XVII wieku // Modernizacja struktur władzy w warunkach opóźnienia. Europa Środkowa i Wschodnia na przełomie średniowiecza i czasów nowożytnych. Warszawa, 1999. S. 202-203. ${ }^{31}$ Usarze...; Komput wojska JKM...

${ }^{32}$ S. Koniecpolski to Sigismund III, Busk, 14.IV.1629 // Biblioteka Muzeum Książąt Czartoryskich. MS 357. S. 1080, in which the hetman informs the monarch that only two people agreeed to accept a recruitment letter and recruit a new hussar chorągiew; see: The letter of Primate Jan Wężyk to Sigismund III, Łowicz, 25.IV.1629 // Biblioteka Muzeum Książąt Czartoryskich. MS 357. S. 1088. 
recruitment abroad played a role in the process, mainly as a result of the Thirty Years' War. The structure of the cavalry was still dominated by Polish hussars and light Cossacks cavalry; German reiters constitute c. $18 \%$ of the whole cavalry.

The organization of artillery changed the least, relatively. Fiscal accounts allow us to identify numerous expenses towards this from the treasury, which justifies the claim that it was Jan Waxman, in charge of the Warsaw armory, who managed the delivery of cannons, artillery equipment, and ammunition. Waxman received the money to buy gunpowder and artillery equipment and to pay craftsmen working in Warsaw. The armory manager also delivered cannons and equipment to the camp. The Treasury also paid gunsmiths and their helpers who dealt with the service of cannons in Prussia, in the years 1628-1629 allotting for this purpose over 15,000 zlotys, which was quite an sum of money for those days ${ }^{33}$. On the other hand, Michat Paradowski presumed that the office of the starszy nad armatą (lit. senior over the cannon; the commander of artillery) in Prussia was held by Bazyli Judycki. However, he did not give the source for this statement. Indeed, during the fights at Malbork, the knight of Malta managed the artillery fire, but there is still no evidence that he held the office of starszy ${ }^{34}$. However, the Swedish advantage in the field is beyond discussion, as it was visible during clashes in field as well as positional and siege operations ${ }^{35}$. It was, however, one of the manifestations of the Crown troops' weakness in military technology. The hetman had problems not only with artillery, but also with finding well prepared military engineers and sappers ${ }^{36}$.

Undoubtedly, the war for the Vistula Mouth left its imprint on the organization of the Crown army. The size of the army increased, at least on paper, where dragoons and infantry gained more importance, especially those of the foreign model contingent ${ }^{37}$. The organizational structure of the infantry changed, where large regiments of even 3,000 pay rates almost entirely superseded independent companies. The old organizational model survived in the dragoons. First attempts were made to create units trained and armed in a foreign manner in the form of Rosen's regiment in 1629. The newly appointed captain commanded the expanded Polish-Hungarian model infantry. In the ranks of cavalry German reiters played an important role, especially before the wojsko kwarciane (Quarter Troops) arrived in Prussia. We should not ignore the question, not mentioned in this article and deserving a separate paper, of provisioning the army and creating a semi-permanent office or committee dealing

\footnotetext{
${ }^{33}$ Regestrum rationis... S. 520-523; Rachunek skarbu koronnego... S. 36.

${ }^{34}$ Paradowski M. Despite destruction... S. 42; Kontynuacja diariusza... S. 440.

${ }_{35}$ The siege of Mewe (Gniew): Teodorczyk J. Bitwa pod Gniewem...; battle of Dirschau (Polish Tczew): Bielski M., Rezmer $W$. Bitwy na Pomorzu. Szkice z dziejów militarnych Pomorza Nadwiślańskiego (1109-1945). Gdańsk, 1993. S. 173; struggles near Marienburg (Polish Malbork): Kontynuacja diariusza... S. 443-444.

${ }^{36}$ S. Koniecpolski to Sigismund III, Puck, 3.IV.1627 // Biblioteka Jagiellońska. MS 211. F. 95; T. Zamoyski to S. Łubieński, s. l. s. a. // Biblioteka Muzeum Książąt Czartoryskich w Krakowie. MS 119. Nr 5. S. 17. - It is important to underscore the overwhelming superiority of the Swedes in terms of military cartography, which was demonstrated: Łopatecki K., Walczak W. Mapy i plany Rzeczypospolitej XVII w., znajdujące się w znajdujące się w archiwach w Sztokholmie. T. I. Warszawa, 2011. S. 28-43.

${ }^{37}$ The consequence thereof was, for example, preparing special military laws for dragoon units (before 1628) and probably German reiters: Łopatecki K. «Disciplina militaris» w wojskach Rzeczypospolitej do połowy XVII wieku. Białystok, 2012. S. 502-505.
} 
with delivering food to the camp, as well as purchasing and delivering military equipment, particularly gunpowder, to the camp.

Two other questions now emerge: about the effectiveness of the aforementioned transformations and their durability. It cannot be denied that the Crown army was most successful when it managed to force the enemy to adopt the traditional manner of warfare. A maneuver surprising the enemy and the speed of the cavalry's actions were behind the victorious clashes of Czarne (Hamersztyn) and Trzciane, and cavalry raids forced Gustav II Adolf to abandon his march towards Graudenz (Polish Grudziądz) and to retreat northwards during the struggles in the summer 1628, even though in the latter case, it was important to block the way of the Swedes' march by Koniecpolski's camp. The hetman was able to defend himself effectively, to initiate raids and to maneuver, but for the deficiency of infantry, artillery, sappers, and money he could not force the Swedes to accept a major battle on favorable terms for the Poles. Hence the request for the emperor's aid, first in the form of 3,000 soldiers of Duke Adolf of Holstein in 1627, and then reinforcements from Wallenstein's army under the command of Johann Georg von Arnheim (Arnim).

Figure 4. Organization of Crown Army in 1630-1631

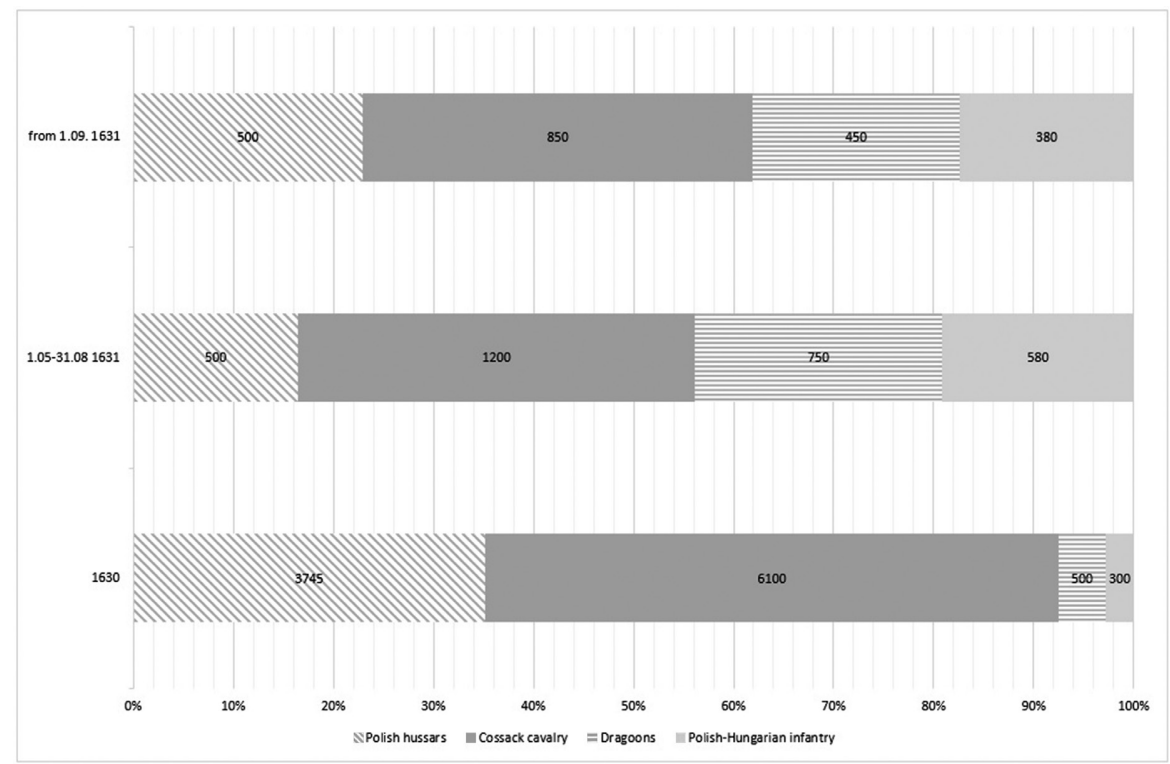

Prepared by the author on the basis of: Wimmer J. Wojsko i skarb Rzeczypospolitej u schyłku XVI i w pierwszej połowie XVII wieku // Studia i materiały do historii wojskowości. 1968. T. XIV. Cz. 1. S. 56-58.

The Crown Treasury did not bear the burden of the war, which cost a staggering amount of over 10 million zlotys, according to Anna Filipczak-Kocur's estimation ${ }^{38}$. The debt was so serious that the next day after the Altmark armistice the reduction of the army began, with losses falling primarily on foreign contingent units. In 1630, Koniecpolski's army remaining

${ }^{38}$ Filipczak-Kocur A. Skarbowość Rzeczypospolitej 1587-1648. Projekty — ustawy — realizacja. Warszawa, 2006. S. 156. 
to protect the south-eastern border had nominally 3,745 horses of hussars, 6,100 horses of Cossacks, 500 dragoons, and 300 of Polish-Hungarian model infantry ${ }^{39}$. Its form thus, was a retreat from the Prussian experiences: the considerable reduction of the number of cavalry and an almost total abandonment of foreign recruitment, not counting a small group of dragoons. However, Koniecpolski appreciated the latter formation, planning to bring 1,000 soldiers from Prussia, not only the subordinates of Fryderyk Denhoff but also of Jakub Butler, which eventually did not happen because of difficulties with financing the unit and a rebellion of the subordinates, who refused further service under the command of the colonel ${ }^{40}$. In 1631 ,

Figure 5. Percentage of infantry in the Crown army

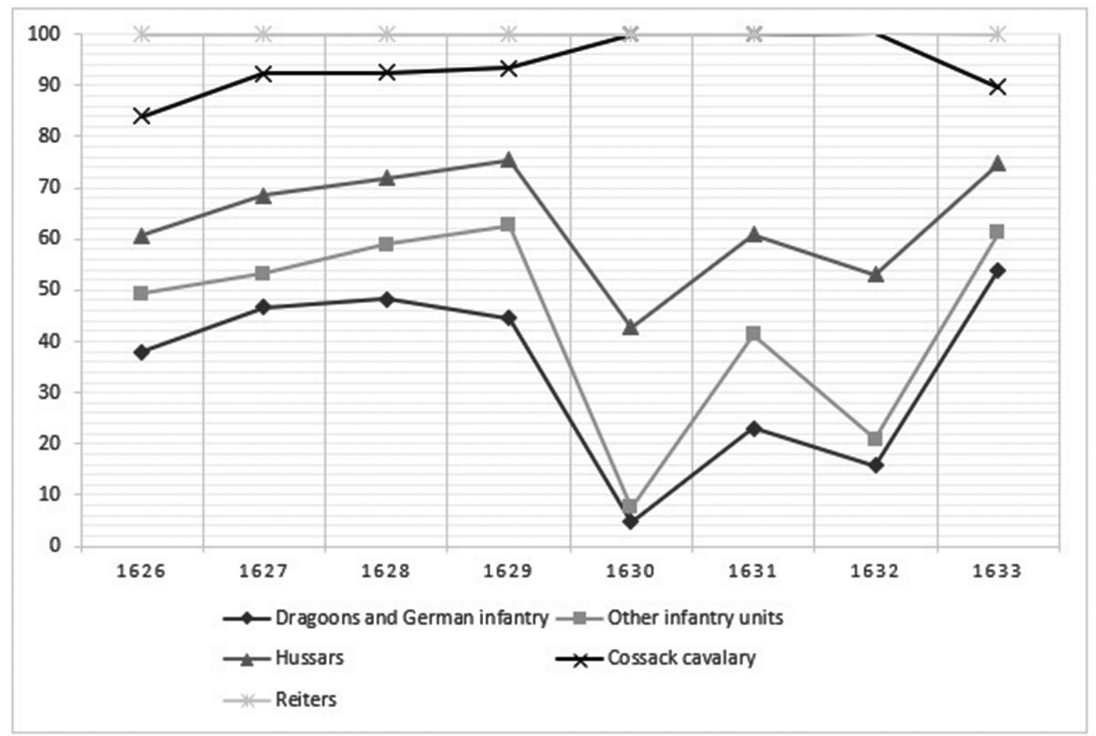

The calculations refer to the northern army in the years 1626-1629, the peace stage of 1630-1632 and prepared recruitments (in 1633) for the needs of the planned relief of Smolensk.

Prepared by the author. Data concerning years $1632-1633$ on the basis: Gawron P. Armia koronna w czasie bezkrólewia po śmierci Zygmunta III Wazy // Wokół wolnych elekcji w państwie polskolitewskim XVI-XVIII wieku. O znaczeniu idei wyboru - między prawa a obowiązkami. Katowice, 2016. S. 233; Treasury accounts on the Coronation Diet in 1633 // AGAD. Archiwum Skarbu Koronnego.

Dz. II. MS 43. F. 1; Biblioteka Zakładu im. Ossolińskich we Wrocławiu. MS 9531. S. 1-122; Solutio stipendiorum militariorum in commissione Leopoliensi iuxta laudum conventus generalis Regni Varsavia MDCXXX quarto anno descriptum, Lwów, 11.І.1635 // ЦДІАУЛ. Ф. 9. Оп. 1. Спр. 386. С. 163-268.

${ }^{39}$ Wimmer J. Wojsko i skarb... S. 56-57.

${ }^{40}$ Sigismund III to commisars for soldier's pay in Inowrocław, [s. 1 et a.] // Biblioteka Muzeum Książąt Czartoryskich w Krakowie. MS 359. S. 413; Sigismund III to commisars for soldier's pay in Inowrocław, [s. 1 et a.], Warszawa, 6.V.1630 // Ibid. S. 469; Sigismund III to commisars for soldier's pay in Inowrocław, [s. 1 et a.], Warszawa, 31.V.1630 // Ibid. S. 479; Sigismund III to S. Koniecpolski, Warszawa, 2.VI.1630 // Ibid. S. 482; Sigismund III to nobility and gentry, Warszawa, 11.VI.1630 // Ibid. S. 490; Sigismund III to commisars for soldiers' pay in Toruń, Warszawa, 14.VI.1630 // Ibid. S. 493; Sigismund III to James Butler's soldiers, Warszawa, 14.VI.1630 // Ibid. S. 494; Sigismund III to S. Koniecpolski, Warszawa, 22.V.1630 // Ibid. MS 365. S. 165. 
when a subsequent reduction was planned, there were 1,000 dragoons and 880 infantrymen per 3,100 of cavalry, which may show a certain durability of the Prussian experience ${ }^{41}$. The army's structure is shown on Figure 4 below, percentage of infantry in the Crown army - Figure 5.

However, the strongest confirmation of the way taken by Sigismund III is the army, which his son and descendant, Władysław IV took with him to Smolensk. The infantry of the foreign contingent, in the Crown part organized in regiments of 800-1,200 pay rates, dragoons and Polish infantry constituted $61 \%$ of all the forces, whereas $88 \%$ of the infantry were infantrymen of foreign contingent and dragoons. The king made an effort to create units recruited among Poles who were commanded, trained, and armored in a foreign manner. He did not forget reiters, making $18 \%$ of the whole cavalry, beside hussars, Cossacks, and petyhorcy. He also took care to strengthen the artillery ${ }^{42}$. Thanks to that, he managed to defeat Muscovy's army at Smolensk and force the tsar to sign a peace treaty in Polyanovka favorable for the Commonwealth. It is impossible, however, to avoid the conclusion that without the Prussian experience, organizing that type of army would not be possible, and the changes of 1626-1629 turned out extremely durable.

\section{Информация о статье}

Статья написана в рамках исследовательского проекта Национального научного центра SONATA, № 2016/23/D/HS3/03210 «The military revolution as a modernization factor in the public finance and state organization of the Polish-Lithuanian state in the comparative perspective»

Автор: Гаврон, Пшемыслав - доктор наук, адъюнкт, Университет Кардинала Стефана Вышинского, Варшава, Польша, OrcID 0000-0003-2834-6735; e-mail: p.gawron@uksw.edu.pl

Заголовок: Organizational transformations of the Crown Army during the war of the Vistula mouth, 16261629 [Организационные изменения польской армии во время войны за устье Вислы 1626-1629 гг.]

Резюме: В статье рассматриваются организационные изменения польской армии во время войны со Швецией в 1626-1629 гг. В этот период увеличилось количество войск короля Сигизмунда III, которых в 1629 г. в Пруссии было больше, чем объединенных сил в Пруссии и Украине тремя годами ранее. Позиционная война с хорошо обученной пехотой и отличной шведской артиллерией потребовала изменения структуры армии, половина которой состояла из пехоты (в большей степени наемников) и драгунов. В ходе войны свободные роты (freikompanies), составлявшие основу пехоты, были заменены большими полками, насчитывавшими в составе более 3000 человек. Были предприняты успешные попытки создать пехотные части, обученные и вооруженные по немецкому образцу, под командованием иностранцев (их набирали из числа подданных Сигизмунда III). Были также усилены и ряды польсковенгерской пехоты. В кавалерии большую роль стали играть рейтары, которые выросли до третьей по численности силы после гусар и казаков. Гораздо меньшие изменения произошли в артиллерии, которая, несмотря на значительные затраты, все же уступала шведской. После перемирия в Альтмарке в 1629 г. король сократил армию, из которой почти полностью исчезла пехота. Значение изменений подтверждает тот факт, что в 1633 г., в ходе подготовки Польши к войне с Московским государством за Смоленск, король Владислав IV и его советники организовали армию по образцам 1626-1629 гг.

Ключевые слова: война за устье Вислы, польская армия, шведская армия, Сигизмунд III, Густав II Адольф, военные реформы

\section{Литература, использованная в статье:}

Bielski, Mieczysław; Rezmer, Waldemar. Bitwy na Pomorzu. Szkice z dziejów militarnych Pomorza Nadwiślańskiego (1109-1945). Gdańsk: Wydawnictwo Marpress, 1993. 374 s.

Bołdyrew, Aleksander; Łopatecki, Karol. Polish Way: The Light Cossack Cavalry in the Era of Military Revolution // Vestnik of St. Petersburg University. History. 2020. Vol. 65. Issue 3. P. 683-709.

Filipczak-Kocur, Anna. Skarbowość Rzeczypospolitej 1587-1648. Projekty - ustawy - realizacja. Warszawa: Wydawnictwo Sejmowe, 2006. 438 s.

${ }^{41}$ Wimmer J. Wojsko i skarb... S. 58.

${ }^{42}$ Kupisz D. Smoleńsk 1632-1634. Warszawa, 2017. S. 141-153, 267-268. 
Fredhom von Essen, Michael. The Lion from the North. The Swedish Army during The Thirty Years War. Vol. 1: 1618-1632. Warwick: Helion \& Company, 2020. 272 p.

Frost, Robert I. The Northern Wars. War, State and Society in Northeastern Europe, 1558-1721. Harlow: Longman, 2000. $401 \mathrm{p}$.

Gawron, Przemysław. Armia koronna w czasie bezkrólewia po śmierci Zygmunta III Wazy // Wokół wolnych elekcji w państwie polsko-litewskim XVI-XVIII wieku. O znaczeniu idei wyboru - między prawa a obowiązkami / Red. Mariusz Markiewicz, Dariusz Rolnik, Filip Wolański. Katowice: Wydawnictwo Uniwersytetu Śląskiego, 2016. S. 227-243.

Kupisz, Dariusz. Smoleńsk 1632-1634. Warszawa: Wydawnictwo Bellona, 2017. 293 s.

Kupisz, Dariusz. The Polish-Lithuanian Military in the Reign of King Stefan Bathory (1576-1586) // Warfare in Eastern Europe, 1500-1800 / Ed. by Brian J. Davies. Leiden; Boston: Brill, 2012. P. 63-92.

Łopatecki, Karol. «Disciplina militaris» w wojskach Rzeczypospolitej do połowy XVII wieku. Białystok: Instytut Badań nad Dziedzictwem Kulturowym Europy, 2012. $802 \mathrm{~s}$.

Lopatecki, Karol; Walczak, Wojciech. Mapy i plany Rzeczypospolitej XVII w., znajdujące się w znajdujące się w archiwach w Sztokholmie. T. I. Warszawa: Ministerstwo Kultury i Dziedzictwa Narodowego, 2011. 331 s. Nagielski, Mirosław. Reinhold Rosen // Polski Słownik Biograficzny. T. XXXII. Wrocław: Ossolineum, 1989. S. 60-62.

Nagielski, Mirosław. Staropolska sztuka wojenna na tle przemian w zachodnioeuropejskiej wojskowości w XVII wieku // Modernizacja struktur władzy w warunkach opóźnienia. Europa Środkowa i Wschodnia na przełomie średniowiecza i czasów nowożytnych / Red. Marian Dygo, Sławomir Gawlas, Hieronim Grala. Warszawa: Wydawnictwo DIG, 1999. S. 201-216.

Paradowski, Michat. Despite destruction, misery and privations... The Polish Army in Prussia during the war agaist Sweden 1626-1629, Warwick: Helion\&Company Limited, 2021. 210 s.

Paradowski, Michat. Studia i materiały do historii wojen ze Szwecją 1600-1635. Oświęcim: Wydawnictwo Napoleon V, 2013. 219 s.

Skorupa, Dariusz. Bitwa pod Bukowem 20 października 1600 r. // Staropolska sztuka wojenna XVI-XVIII wieku, Prace ofiarowane Profesorowi Jaremie Maciszewskiemu / Red. Mirosław Nagielski. Warszawa: Wydawnictwo DIG, 2002. S. 17-43.

Teodorczyk, Jerzy. Bitwa pod Gniewem (22.IX-29.IX-1.X.1626). Pierwsza porażka husarii // Studia i Materiały do Historii Wojskowości. 1966. T. XII. Cz. 2. S. 70-172.

Teodorczyk, Jerzy. Wyprawa szwedzka z Meklemburgii do Prus Królewskich wiosną 1627 r. // Studia i Materiały do Historii Wojskowości. 1960. T. VI. S. 100-190.

Wimmer, Jan. Historia piechoty polskiej do roku 1864. Warszawa: Wydawnictwo Ministerstwa Obrony Narodowej, 1978. $616 \mathrm{~s}$.

Wimmer, Jan. Wojsko i skarb Rzeczypospolitej u schyłku XVI i w pierwszej połowie XVII wieku // Studia i Materiały do Historii Wojskowości. 1968. T. XIV. Cz. 1. S. 3-91.

Wisner, Henryk. Wojna inflancka 1625-1629 // Studia i Materiały do Historii Wojskowości. 1970. T. XVI. Cz. 1. S. 27-93.

Żojdź, Karol; Hundert, Zbigniew. Komput chocimski 1621 z rękopisu Biblioteki Narodowej // Studia nad staropolską sztuką wojenną. T. II / Red. Zbigniew Hundert. Oświęcim: Wydawnictwo Napoleon V, 2013. S. 245-257.

Information about the article

The article was written as part of the research project of the National Centre for Science SONATA, no. 2016/23/D/HS3/03210 «The military revolution as a modernization factor in the public finance and state organization of the Polish-Lithuanian state in the comparative perspective».

Author: Gawron, Przemysław - Dr., adiunkt, Cardinal Stefan Wyszyński University, Warsaw, Poland, OrcID 0000-0003-2834-6735; e-mail: p.gawron@uksw.edu.pl

Title: Organizational transformations of the Crown Army during the war of the Vistula mouth, 1626-1629

Summary: The article explores the organizational transformations of the Crown army during the war with Sweden in the years 1626-1629. On the basis of fiscal sources, correspondence, and war accounts, the author established that the number of Sigismund III's troops increased. In 1629 they were more numerous in Prussia than the combined armies in Prussia and in Ukraine three years earlier. Positional warfare with the Swedes, who had a considerable number of well-trained infantry and perfect artillery, required a change in the structure of the army, over half of which during hostilities consisted of dragoons and 
infantry formations, especially those of the foreign contingent. Over the course of the war, free companies (freikompanie), which made up a core of the infantry at the beginning of the war, were mostly replaced by large regiments of over three thousand pay rates. Also, successful attempts were made to create infantry units trained and armed in the German manner, commanded by foreigners, but recruited among Sigismund III's subjects, and the ranks of Polish-Hungarian infantry were reinforced. In the ranks of cavalry, reiters were of more importance than in Ukraine. They grew into a third force in the Polish cavalry, after Polish hussars and Cossacks. Considerably smaller changes occurred for artillery, which despite significant expenses was still inferior to that of the Swedish artillery. Sigismund III's troops also struggled with the deficiency of experienced engineers and cartographers. Although after the Altmark armistice the king had to reduce the army, from which the infantry disappeared almost entirely, dragoons were preserved in Ukraine thanks to Crown Field Hetman Koniecpolski. From that time on, they would constitute an indispensable part of the wojsko kwarciane (quarter army). The significance of the Prussian war for the development of the Crown military is best illustrated by the fact that in 1633, in the course of preparations for the war with Muscovy for Smolensk, Władysław IV and his advisers organized the army largely in the manner of the years $1626-1629$.

Keywords: War for the Vistula mouth, Crown army, Swedish army, Sigismund III, Gustav II Adolf, military reforms

\section{References:}

Bielski, Mieczysław; Rezmer, Waldemar. Bitwy na Pomorzu. Szkice z dziejów militarnych Pomorza Nadwiślańskiego (1109-1945) [Battles in Pomerania: Sketches from the military history of the Pomeranian Vistula (1109-1945)]. Gdask: Wydawnictwo Marpress Publ., 1993. 374 p. (in Polish).

Bołdyrew, Aleksander; Łopatecki, Karol. Polish Way: The Light Cossack Cavalry in the Era of Military Revolution, in Vestnik of St. Petersburg University. History. 2020. Vol. 65. Issue 3. Pp. 683-709.

Filipczak-Kocur, Anna. Skarbowość Rzeczypospolitej 1587-1648. Projekty - ustawy - realizacja [The Commonwealth'Treasury 1587-1648. Projects - statutes - realization]. Warsaw: Wydawnictwo Sejmowe Publ., 2006. 438 p. (in Polish).

Fredhom von Essen, Michael. The Lion from the North. The Swedish Army during The Thirty Years War. Vol. 1: 1618-1632. Warwick: Helion \& Company Publ., 2020. 272 p.

Frost, Robert I. The Northern Wars. War, State and Society in Northeastern Europe, 1558-1721. Harlow: Longman Publ., 2000. 401 p.

Gawron, Przemysław. Armia koronna w czasie bezkrólewia po śmierci Zygmunta III Wazy [The Polish army during the interregnum after the death of Sigismund III], in Markiewicz, Mariusz; Rolnik, Dariusz; Wolański, Filip (eds). Wokół wolnych elekcji w państwie polsko-litewskim XVI-XVIII wieku. O znaczeniu idei wyboru - między prawa a obowiazkami. Katowice: Wydawnictwo Uniwersytetu Śląskiego Publ., 2016. Pp. 227-243. (in Polish).

Kupisz, Dariusz. Smoleńsk 1632-1634 [Smolensk 1632-1634]. Warsaw: Wydawnictwo Bellona Publ., 2017. 293 p. (in Polish).

Kupisz, Dariusz. The Polish-Lithuanian Military in the Reign of King Stefan Bathory (1576-1586), in Davies, Brian J. (ed.). Warfare in Eastern Europe, 1500-1800. Leiden; Boston: Brill Publ., 2012. Pp. 63-92.

Łopatecki, Karol. «Disciplina militaris» w wojskach Rzeczypospolitej do połowy XVII wieku [«The Military discipline» in Commonwealth' armies up till first half of the 17 th century]. Bialystok: Instytut Badan nad Dziedzictwem Kulturowym Europy Press, 2012. 802 p. (in Polish).

Łopatecki, Karol; Walczak, Wojciech. Mapy i plany Rzeczypospolitej XVII w., znajdujace się w znajdujace się $w$ archiwach $w$ Sztokholmie [Maps and plans of Commonwealth in the $17^{\text {th }}$ century in Stockholm archives]. Vol. I. Warsaw: Ministerstwo Kultury i Dziedzictwa Narodowego Publ., 2011. 331 p. (in Polish).

Nagielski, Mirosław. Reinhold Rosen, in Polski Stownik Biograficzny. Vol. XXXII. Wrocław: Ossolineum Publ., 1989. Pp. 60-62. (in Polish).

Nagielski, Mirosław. Staropolska sztuka wojenna na tle przemian w zachodnioeuropejskiej wojskowości w XVII wieku [The Ancient Polish art of war in context of transformation of Western European warfare in the $17^{\text {th }}$ century], in Dygo, Marian; Gawlas, Sławomir; Grala, Hieronim (eds). Modernizacja struktur władzy w warunkach opóźnienia. Europa Środkowa i Wschodnia na przełomie średniowiecza i czasów nowożytnych. Warsaw: Wydawnictwo DIG Publ., 1999. Pp. 201-216. (in Polish).

Paradowski, Michał. Despite destruction, misery and privations... The Polish Army in Prussia during the war agaist Sweden 1626-1629. Warwick: Helion\&Company Limited, 2021, 210 p. 
Paradowski, Michał. Studia i materiaty do historii wojen ze Szwecja 1600-1635 [Studies and Materials to history of Wars against Swedes, 1600-1635]. Oswiecim: Wydawnictwo Napoleon V Publ., 2013. 219 p. (in Polish).

Skorupa, Dariusz. Bitwa pod Bukowem 20 października 1600 r. [Battle of Bucau, October 20, 1600], in Nagielski, Mirosław (ed.). Staropolska sztuka wojenna XVI-XVIII wieku, Prace ofiarowane Profesorowi Jaremie Maciszewskiemu. Warsaw: Wydawnictwo DIG Publ., 2002. Pp. 17-43. (in Polish).

Teodorczyk, Jerzy. Bitwa pod Gniewem (22.IX-29.IX-1.X.1626). Pierwsza porażka husarii [Battle of Gniew (22.IX-29.IX-1.X.1626). First defeat of Polish Hussars], in Studia i Materiały do Historii Wojskowości. 1966. Vol. XII. Part 2. Pp. 70-172. (in Polish).

Teodorczyk, Jerzy. Wyprawa szwedzka z Meklemburgii do Prus Królewskich wiosną 1627 r. [Swedish expedition from Meklemburg to Royal Prussia in the spring of 1627], in Studia i Materiaty do Historii Wojskowości. 1960. Vol. VI. Pp. 100-190. (in Polish).

Wimmer, Jan. Historia piechoty polskiej do roku 1864 [History of Polish Infantry till 1864]. Warsaw: Wydawnictwo Ministerstwa Obrony Narodowej Publ., 1978. 616 p. (in Polish).

Wimmer, Jan. Wojsko i skarb Rzeczypospolitej u schyłku XVI i w pierwszej połowie XVII wieku [War and Commonwealth' Treasure in the end of the $16^{\text {th }}$ and first half of the $17^{\text {th }}$ century], in Studia i Materiaty do Historii Wojskowości. 1968. Vol. XIV. Part 1. Pp. 3-91. (in Polish).

Wisner, Henryk. Wojna inflancka 1625-1629 [The Livonian War, 1625-1629], in Studia i Materiaty do Historii Wojskowości. 1970. Vol. XVI. Part 1. Pp. 27-93. (in Polish).

Żojdź, Karol; Hundert, Zbigniew. Komput chocimski 1621 z rękopisu Biblioteki Narodowej [The Military Register of Polish-Lithuania Army during Khotin campaign in 1621 acccording to Manuscript from National Library in Warsaw], in Hundert, Zbigniew (ed.). Studia nad staropolska sztuka wojenna. Vol. II. Oswiecim: Wydawnictwo Napoleon V Publ., 2013. Pp. 245-257. (in Polish). 